УДК 68.41

DOI: 10.31453/kdu.ru.978-5-7913-1143-6-2020-171-177

Коколова Людмила Михайловна Гаврильева Любовь Юрьевна Якутский научно-исследовательский институт сельского хозяйства имени М.Г. Сафронова - обособленное подразделение Федерального государственного бюджетного. учреждения науки Федеральный исследовательский центр «Якутский научный центр, Сибирского отделения Российской академии наук» г. Якутск, Россия

Корякина Мария Сергеевна

Государственное бюджетное профессиональное образовательное учреждение Республики Саха (Якутия)

"Якутский сельскохозяйственный техникум"

агротехнологическое отделение

\title{
ВЛИЯНИЕ РАННЕГО ПОТЕПЛЕНИЯ НА РАЗВИТИЕ ВЛАСОЕДОВ - TRICHODECTES PILOSUS У ЛОШАДЕЙ ТАБУННОГО СОДЕРЖАНИЯ
}

\section{INFLUENCE OF EARLY WARMING ON THE DEVELOPMENT OF WHIPWORMS-TRICHODECTES PILOSUS IN HORSES OF HERD CONTENT}

Аннотация. Якутская лошадь является самой северной разновидностью лошадиного племени в мире, и является единственной лошадью, которая адаптирована к пастбищному содержанию в течение всего года. Содержания и кормления лошадей в табунном коневодстве организовано при круглогодичном использовании естественных пастбищ, в связи с этим упитанность табунных лошадей, их плодовитость и уровень продуктивности полностью зависят от состояния и уровня достаточного корма тебеневочных пастбищ. При обеспечении хорошим кормом лошадь в условиях суровой зимы не только выживает, но и дает здоровое потомство. Вместе с тем, проблема инвазирования и распространение эктопаразитов власоедов Trichodectes pilosus у лошадей табунного содержания остается весьма актуальной проблемой. Распространение, которых связано с действием различных причин биотического, абиотического, климатического характера и прежде всего наличие возбудителя, особенности его биологии, характера их циркуляции в природном биоценозе и пути передач.

Abstract. The Yakut horse is the north variety of horse tribe in the world, and is an only forest horse that is adapted to pascual maintenance during throughout the year. The tables of contents and feeding of horse in the herd horse breeding are organized at the whole-year use of natural pastures, 
in this connection fatness of herd horse, their fecundity and level of the productivity fully depend on the state and level of sufficient feed of pasturing of animals. At providing a good feed a horse not only survives in the conditions of severe winter but also gives healthy posterity. At providing a good feed a horse not only survives in the conditions of severe winter but also gives healthy posterity. At the same time, problem of invasion and distribution of actoparasitis Trichodectes pilosus for the horse of herd maintenance remains the very issue of the day. Distribution of that is related to the action of different reasons of biotic, abiotical factor, climatic character and foremost presence of causative agent, feature of his biology, character of their circulation in a natural biocenosis and way of transmissions.

Ключевые слова: потепление, весна, температура, лошади, климат, вид Trichodectes pilosus, проблема.

Keywords: rise in temperature, spring, temperature, horse, climate, type of Trichodectes pilosus, problem.

В настоящее время, в Республике Саха (Якутия) табунное коневодство распространено практически повсеместно и имеет как продуктивное, так и рабочее направление. Поэтому, особое значение имеет рациональное и грамотное использование пастбищ в зависимости от сезона и климатических условий нашего региона. В период тебеневки организм лошадей кроме недостаточности грубых кормов испытывает нехватку питательных веществ, этот процесс еще усугубляется паразитирование в организме животных.

Коневодство в Якутии тесно связано с традициями населяющего эту республику народа саха. Лошадь в Якутии с давних времен, верно служит человеку в суровых условиях этого холодного края, не только являясь для него средством передвижения, но и обеспечивая мясом, молоком и шкурами. Республика Саха (Якутия) является уникальным регионом России с резко континентальным климатом. Среднегодовой перепад температур порой достигает 100 градусов (летом температура поднимается до плюс 40-ка, а в зимнее время падает до минус 50-ти - 60-ти градусов). Такие суровые условия закалили якутских лошадей, которые хорошо переносят и летний зной, и зимнюю стужу. Кроме того, густой шерстный покров хорошо защищает этих 
животных от многочисленных кровососущих насекомых (мошкара, комары, оводы), тучи которых летом досаждают всем живым существам.

Основной задачей коневодства Якутии является дальнейшее увеличение поголовья лошадей, повышение продуктивности и снижение себестоимости, развитием прочной кормовой базы и с проведением ветеринарных мероприятий по ликвидации потерь животных от различных болезней, в частности, вызываемых гельминтами.

Гельминтозы лошадей табунного содержания распространены повсеместно и в большинстве случаев имеют хроническое течение без ярко выраженных клинических проявлений, при бессимптомном течении гельминтозов (субклиническая форма) причиняется огромный экономический ущерб, который определяется снижением продуктивности, потерей привесов, задержкой роста и плохим развитием молодняка. $\mathrm{K}$ числу широко распространенных заболеваний лошадей относятся стронгилятоз, параскаридоз и оксиуроз (С.И. Исаков, 1971; Л.М. Коколова, В.М. Сафронов и др., 2013; В.А. Большакова, 1998; Коколова Л.М., Григорьев В.П. и др., 2000; Л.Ю. Гаврильева, 2014; Л.М. Коколова, Л.Ю. Гаврильева, 2019). Зараженность лошадей Strongylus equinus, Parascaris equorum и Охуuris equi в отдельных коневодческих хозяйствах достигает 90-100\%. В связи с создавшейся обстановкой изучение этих нематодозов в местных природно-климатических условиях и разработка мер борьбы и их профилактика явились весьма актуальной проблемой, но развитие и распространение власоедов - Trichodectes pilosus у лошадей табунного содержания в Якутии связано с действием различных причин биотического, абиотического, климатического характера. Биотический фактор имеет решающее значение, это, прежде всего наличие возбудителя, особенности его биологии, характера их циркуляции в природном биоценозе и пути передачи. Абиотическими причинами для распространения гельминтозов являются метеорологические факторы: температура, влажность, атмосферные осадки, солнечный свет. Располагая данными о сумме эффективных температур, необходимых для созревания яиц и личинок гельминтов, насекомых, стадий их 
развития, можно для любой местности определить сроки, наиболее опасные для возможного заражения лошадей, а также предполагать интенсивность заражения и их распространение.

Цель изучение распространения власоедов у лошадей табунного содержания в западной зоне определить сроки, наиболее опасные для возможного заражения всего поголовья лошадей,

Нами проведен клинический осмотр и сбор власоедов от 10 кобыл, 9 жеребят и жеребца лошади табунного содержания в КХ «Сырдык Суол» Сунтарского района. Дифференциальную диагностику власоедов определяли по Н.Н. Плавильщикову.

Проведено лечение инвазированных лошадей власоедом. Животным применяли препарат «Аверсект-2» внутрикожно из расчета 0,1 мл препарата на 100 кг массы тела (что соответствует 0,2 мг/кг по ДВ) в область предплечья, однократно, а также опрыскивали «Энтомозаном-С»-0,01\% (1:1000) водной препарата, двукратно с интервалом 10 дней. Перед дезинсекцией в присутствии животных из загона предварительно убирали остатки корма и воды. Животных выдерживали в течение 1,5 часа после обработки, затем только выпускали из загона. Все работы с «Энтомозаном-С» следует провести с использованием меры личной гигиены.

Одной из серьезных проблем развития эктопаразитов у животных стало наступление раннего тепла, хотя говорить о приходе весны в начале апреля еще рановато, но яркие солнечные лучи сильно греют поверхность, при этом греясь на лучах яркого солнца лошади, сильно потеют и появляются эктопаразиты. В третьей декаде марта днем преобладающая температура при солнце достигала $6^{\circ} . .11^{\circ}$ тепла, ночью воздух будет не так сильно охлаждался был с небольшими холодами до $-1 \ldots 6^{\circ}$.

Власоеды развиваются у млекопитающих, они принадлежат к отряду Mallophaga. Отряд Mallophaga включает до 2500 видов, из них около 50 паразитирует у млекопитающих, а остальные у птиц. Власоеды паразитируя у домашних животных сильно беспокоят, как мы знаем у крупного рогатого скота 
паразитирует Trichodectes bovis, у овец - Trichodectes ovis, у лошадей Trichodectes pilosus, у собак - Trichodectes canis, у кошек - Trichodectes subrostratus. Питаются власоеды эпидермальными клетками, выделениями сальных желёз и кровью. У животных вызывают зуд, расчёсы, выпадение волос и гиперкератоз кожи. Власоеды могут быть переносчиками возбудителей инфекционных и инвазионных болезней (инфекционная анемия лошадей, дипилидиоз плотоядных и других животных). Насекомые используют млекопитающих только в качестве источника питания. Самка питается кровью перед тем, как отложить яйца. Время выхода личинки из яйца зависит от температурных условий и влажности. Trichodectes pilosus желто-серого оттенка небольшого размера, вытянуты, имеют узкое тело. У насекомого небольшая голова и слабый хитиновый панцирь. Ротовой аппарат приспособлен исключительно для прокалывания кожи хозяина и высасывания крови, они используют тело хозяина для питания и размножения, прикрепляют яйца к шерсти. На воздухе клейкое вещество быстро твердеет и яйцо плотно фиксируется на шерсти. На лошадях со светлой шерстью заметить яйца и власоедов и вшей достаточно сложно, но на лошадях с темным окрасом четко видны светлые гниды на остевых волосках, а также сами эктопаразиты. Самки власоеда в течение всей жизни откладывают до 70 белых яиц овальной формы размером до 15 мм., скорлупа оснащена специальными крючками для повышения сцепления с шерстью хозяина, инкубационный период для яиц составляет 3 недели, скорость размножения паразитов очень высока. Trichodectes pilosus по внешнему виду имеют незначительное сходство со вшами, отличаются наличием ротового аппарата грызущего типа и более массивной головой. Насекомые имеют три пары лапок, с помощью которых прочно фиксируются на теле животного питаются насекомые частицами волос, эпидермисом, сальными выделениями, кровью и лимфой животных.

Наличие паразитических насекомых установили по характерным признакам:

- на теле животных наблюдаются облысевшие участки; 
- отмечаются очаги расчесов и воспалительные процессы в поврежденном кожном покрове;

- появляются зуд и раздражение;

- у некоторых лошадей наблюдается развитие дерматитов.

В холодное время года, когда у лошадей густеет шерсть, они переползают на тело и своими укусами вызывают сильный зуд. Зараженные лошади усиленно расчесывают кожу, трутся о деревья, изгороди. На их теле появляются расчесы и проплешины в области шеи, плеч, паха, корня хвоста, иногда сопровождающиеся небольшими капиллярными кровотечениями. Развивается дерматит, животные истощаются и быстро устают.

У исследованных нами разновозрастных лошадей в табуне власоеды обнаружены у всех 100\%. При клиническом осмотре на участках кожи, заселенных власоедами, волос взъерошен, неодинаковой длины. Между волосами находятся большое количество отслоившегося эпидермиса и скорлупа власоедов, также обнаружены плешины и очаговые дерматиты в области шеи, плеч, пахов, корня хвоста. Наблюдается зуд у лошадей. При исследовании волос обнаружили Trichodectes pilosus, мелкие бескрылые насекомые желтого или светло-коричневого цвета. Проведено лечении лошадей препаратами «Аверсект - 2» внутрикожно из расчета 0,1 мл препарата на 100 кг массы тела (что соответствует 0,2 мг/кг по ДВ), на месте инъекции препарата образовался горошина диаметром примерно 8 мм и препарат «Энтомозан - С» от власоедов опрыскивали 0,01\% (1:1000) водной препарата из расчета 0,3 л обработали двукратно паховые части тела, гриву и хвосты в теплое время дня, все 20 голов лошадей освободились от эктопаразитов, эффективность лечение составило $100 \%$.

Выводы. Таким образом, в условиях Западной Якутии, впервые обнаружены власоеды лошадей - Trichodectes pilosus, 100\% пораженностью поголовья лошадей в данном хозяйстве. В связи с этим, необходимо проводить строгий контроль за ветеринарно-санитарным состоянием животных и мест их 
содержания, а также своевременную изоляцию поражённых животных во избежание распространения данного эктопаразита.

\section{Библиографический список:}

1. Большакова В.А. Нематодозы пищеварительного канала лошадей республики Саха (Якутия) и усовершенствование мер борьбы с ними: автореф. дис. ... канд. вет. наук / В.А. Большакова. - М., - 1998. - 25 с.

2. Гаврильева Л.Ю. Основные стронгилятозы лошадей табунного содержания и мероприятия по борьбе с ними: автореф. дис. ...канд.вет.наук. Москва, 2014 - 14 с.

3. Исаков С.И. Гельминтозы лошадей в условиях косячно-табунного содержания и терапия этих заболеваний // Вредные насекомые и гельминтозы Якутии: Сб. ин-та биологии Якутск. Филиала СО АН СССР. - Якутск, 1971. - С. $109-115$.

4. Коколова Л.М. Применение антигельминтных препаратов против гельминтозов и оводовых инвазий у табунных лошадей в Якутии/ С.И. Исаков, Л.М. Коколова, Л.А. Верховцева, В.П. Григорьев// Сб. научн. тр. «Достижение науки в производстве». - Якутск, 2000. - С. 122-125.

5. Коколова Л.М. Эпизоотологическая ситуация по зоонозам и паразитарным болезням животных и рыб в Якутии/ Л.М. Коколова, В.М. Сафронов, Л.Ю. Гаврильева// Вестник СВФУ. - 2013. - Т. 9. - № 3. - С. 86-90

6. Коколова, Л.М., Гаврильева Л.Ю. 2014. Эффективность применения антгельминтного препарата «Эквисект» паста для профилактики кишечных стронгилятозов лошадей табунного содержания» / C.M. Степанова, Л.М. Коколова, Л.Ю. Гаврильева // Сб. мат. Х республиканского форума МСХА и IX Республиканской научно-практ. конф. молодых исследователей посв. 70-летию Готовцеву М.Н. - Якутск. - 2016. - С.23-25. 